Research Article

\title{
Comparison of the Emotional Intelligence Levels of Students Receiving Education in Different Fields
}

\author{
Zeynep Karaman Özlü, Gülçin Avşar, Kübra Gökalp, Serap Ejder Apay, \\ Özlem Şahın Altun, and Afife Yurttaş
}

Faculty of Health Sciences, Atatürk University, Erzurum, Turkey

Correspondence should be addressed to Gülçin Avşar; gulcin-avsar@hotmail.com

Received 7 June 2016; Accepted 31 October 2016

Academic Editor: Paul S. Szalay

Copyright ( 2016 Zeynep Karaman Özlü et al. This is an open access article distributed under the Creative Commons Attribution License, which permits unrestricted use, distribution, and reproduction in any medium, provided the original work is properly cited.

\begin{abstract}
Aim. This descriptive study was conducted to determine and compare the emotional intelligence levels of senior students receiving education in different fields of Ataturk University. Methods. The population of the study consisted of senior students receiving education in different fields of Atatürk University. The sample group of study consisted of 305 senior students receiving education in different fields (health, social, and natural) and they were selected by using the simple random sampling method. Three faculties from three different fields were selected. Data of the study were obtained by using the personal information form, which was prepared by researchers in the light of the literature and involved sociodemographic characteristics and the "Emotional Intelligence Evaluation Scale." Results. It was determined that while natural science students had the lowest total mean score of emotional intelligence scale, students of social sciences had the highest total mean score according to departments. Examining the difference between the mean scores of three different educational fields, it was determined that this difference was statistically significant. Conclusion. Consequently, the emotional intelligence level was determined to be lower in natural science students and moderate in students of health and social sciences.
\end{abstract}

\section{Background}

Even though various studies have been conducted regarding emotions until today, the concept of "emotional intelligence" was presented for the first time by Salovey and Mayer (1989) [1]. Salovey and Mayer (1989) defined the emotional intelligence as the skill of understanding and questioning with feelings, internalizing the emotions within thoughts, and regulating the emotions in self and others [1-4]. Then, this concept started to be discussed in many fields with a great attention upon publication of the book Emotional Intelligence of the Journalist Daniel Goleman, having the title of Ph.D. in the field of psychology, in 1995. Goleman, on the other hand, defines the emotional intelligence as the skill of recognizing and understanding emotions of our own and others, motivating the self, and managing our emotions in ourselves and our relations accurately $[5,6]$.

Goleman collected the emotional intelligence under five main titles as awareness of emotions, management of emotions, self-motivation, empathy, and social skills. Every individual might differ in terms of the skills of emotional intelligence in these five different fields [5, 7-9].

Considering the studies conducted inland, it is seen that the number of studies on emotional intelligence has increased as from 2000. There are numerous studies revealing the importance of emotional intelligence especially in the management and business fields. Another field that attaches importance to emotional intelligence after the business world is the field of education. Studies conducted in this field indicate that the importance of the concept of emotional intelligence has been noted. The study group generally consists of students in studies conducted in the field of education. These studies aim to approach the emotional intelligence levels of students in terms of several variables and reveal the relationship between them. In these studies, significant relations were determined between emotional intelligence levels and social skill level, interpersonal relation styles, commitment styles, and decision-making strategies [10-13]. Considering 
the studies conducted abroad regarding emotional intelligence, it is seen that there is a very wide range of research and variables, which are investigated in terms of their relation with emotional intelligence after the comprehension of importance of emotional intelligence during the 1990s.

It is reported that, being different from the intelligence quotient, the emotional intelligence is emphasized to have no relation with fate and to possibly develop with education, which increases the importance of emotional intelligence even more [14]. The first education of an individual living in a society undoubtedly starts with family, which is followed by school. Since the education at schools is only based on giving information, the emotional intelligence plays a key role in enhancing the success of individual in both business and private life. It is seen that students are required to develop their emotional intelligence during their education before beginning to work and training programs are required to support this development at universities, where human relations are extremely important. This will establish a ground for training students who can know and motivate themselves, manage their emotions, have a high empathy power, control their relations, and consequently cope with their problems and realize themselves. Based on these facts, this descriptive study was conducted to determine and compare the emotional intelligence levels of senior students receiving education (natural, social, and equally weighted) in different fields of Atatürk University.

\section{Methods}

2.1. Type of Study. The study was conducted as a descriptive and cross-sectional study.

2.2. Population and Sample Group of Study. The population of the study consisted of students of three different areas of faculties in Ataturk University. The sample group of study, on the other hand, consisted of 305 senior students, who were voluntary to participate in the study, received education in different fields (health, social, and natural) of Atatürk University between November 2011 and December 2011, and were selected by using the simple random sampling method. Three faculties from three different fields were selected. The related faculties were enumerated and the simple random table was used in the selection of these faculties.

2.3. Data Collection. Data of the study were obtained by using the personal information form, which was prepared by researchers in the light of the literature $[6,8,9,15,16]$ and involved sociodemographic characteristics, and the "Emotional Intelligence Evaluation Scale" which was developed by Hall (1999) and Turkish validity and reliability of which was conducted by Ergin (2000) [17]. The Cronbach alpha coefficient of the scale was 0.84 and it was determined as 0.96 in this study. The scale involves five subscales as awareness of emotions (items 1, 2, 4, 17, 19, and 25), managing the emotions (items 3, 7, 8, 10, 18, and 30), motivating the self (items 5, 6, 13, 14,16 , and 22), empathy (items $9,11,20,21,23$, and 28), and social skills (items $12,15,24,26,27$, and 29). This Likert scale consists of 30 items. Answers given to questions in the scale were evaluated by six-point Likert scale (1: strongly disagree; 2: partially disagree; 3: slightly disagree; 4: slightly agree; 5: partially agree; 6: strongly agree). In the calculation of subscales, the scores of answers given to items that comprise that subscale are summed. The total of scores obtained from 30 items is also the total score of the emotional intelligence. Increasing scores show the highness of that subscale of the emotional intelligence. Table 1 illustrates scoring of the Emotional Intelligence Evaluation Scale (Table 1).

2.4. Data Assessment. The data of study were assessed in the computer environment by using percentage and ANOVA tests.

2.5. Study Ethics. Prior to the study, both oral and written permissions were obtained from the faculty administrations participating in the study. Moreover, approval was received from the Ethical Commission at Atatürk University Health Sciences Faculty. Besides, students who participated in the study were informed about the purpose of the study and voluntariness of the study participation and their verbal permissions were obtained before they filled out the questionnaire.

\section{Results}

Table 2 illustrates the sociodemographic characteristics of students and it was determined that students were homogeneous in terms of their sociodemographic characteristics. It was determined that $35.1 \%$ of the students included in the study received education in the field of natural sciences, $34.4 \%$ in health sciences, and $30.5 \%$ in social sciences. It was also determined that more than half of the students $(54.8 \%)$ were in the age range of 22-23 and the majority of them $(52.5 \%)$ were male. Besides, students were asked about the subscale of emotional intelligence expressing them the best and it was generally determined as "awareness of emotions" in natural sciences $(29.9 \%)$ and social sciences $(33.3 \%)$ and "empathy" in health sciences (27.6\%) (Table 2).

Table 3 presents the comparison of total scores and subscale mean scores of the emotional intelligence scale according to departments; and it was seen that while natural sciences students had a lower level of emotional intelligence, students of health and social sciences had a moderate level of emotional intelligence. It was determined that while natural sciences students had the lowest total mean score of emotional intelligence scale $(107.5 \pm 36.1)$, students of social sciences had the highest total mean score $(135.4 \pm 26.3)$ according to departments. Examining the difference between the mean scores of three different educational fields, it was determined that this difference was statistically significant $(p<0.0001)$. As a result of the advanced analysis, the difference was determined to be caused by students receiving education in sciences (subscales, respectively, Bonferroni $=21.22$, 21.56, 21.57, 21.87, 21.41, total score Bonferroni = 107.64).

Examining the subscales of the emotional intelligence, it was determined that social sciences had the highest mean score in subscales of "awareness of emotions" $(27.6 \pm 7.6)$, "managing the emotions" (25.2 \pm 5.5$)$, "motivating the self" 
TABLE 1: Scoring of the Emotional Intelligence Evaluation Scale.

\begin{tabular}{lccr}
\hline Subscales of the scale & Low & Mean scores to be obtained & Hormal \\
\hline Awareness of emotions & 25 and below & $26-30$ & 31 and above \\
Managing the emotions & 26 and below & $27-31$ & 32 and above \\
Motivating the self & 26 and below & $27-30$ & 31 and above \\
Empathy & 25 and below & $26-30$ & 31 and above \\
Social skills & 24 and below & $25-29$ & 30 and above \\
\hline Total score & 129 and below & $130-154$ & 155 and above \\
\hline
\end{tabular}

TABLE 2: Distribution of sociodemographic characteristics of students.

\begin{tabular}{|c|c|c|c|c|c|c|c|c|c|}
\hline \multirow[t]{2}{*}{ Characteristics } & \multicolumn{2}{|c|}{$\begin{array}{l}\text { Natural sciences } \\
(n: 107, \%=35.1)\end{array}$} & \multicolumn{2}{|c|}{$\begin{array}{c}\text { Health sciences } \\
\text { (n: } 105, \%= \\
34.4)\end{array}$} & \multicolumn{2}{|c|}{$\begin{array}{l}\text { Social sciences } \\
(n: 93, \%=30.5)\end{array}$} & \multicolumn{2}{|c|}{$\begin{array}{c}\text { Total } \\
(n=305)\end{array}$} & \multirow[t]{2}{*}{ Test and $p$ value } \\
\hline & Number & $\%$ & Number & $\%$ & Number & $\%$ & Number & $\%$ & \\
\hline \multicolumn{10}{|l|}{ Age group } \\
\hline $20-21$ & 10 & 9.3 & 24 & 22.9 & 13 & 14.0 & 47 & 15.4 & \multirow{3}{*}{$\begin{array}{c}\chi^{2}=9.45 \\
\mathrm{df}=4 \\
p>0.05\end{array}$} \\
\hline $22-23$ & 58 & 54.2 & 56 & 53.3 & 53 & 57.0 & 167 & 54.8 & \\
\hline 24 and older & 39 & 36.4 & 25 & 23.8 & 27 & 29.0 & 91 & 29.8 & \\
\hline \multicolumn{10}{|l|}{ Gender } \\
\hline Female & 41 & 38.3 & 57 & 54.3 & 47 & 50.5 & 145 & 47.5 & \multirow{2}{*}{$\begin{array}{c}\chi^{2}=5.90 \\
\mathrm{df}=2 \\
p>0.05\end{array}$} \\
\hline Male & 66 & 61.7 & 48 & 45.7 & 46 & 49.5 & 160 & 52.5 & \\
\hline \multicolumn{10}{|l|}{ Mother's education } \\
\hline Primary school & 31 & 29.0 & 34 & 32.4 & 31 & 33.3 & 96 & 31.5 & \multirow{4}{*}{$\begin{array}{c}\chi^{2}=8.94 \\
\mathrm{df}=6 \\
p>0.05\end{array}$} \\
\hline Secondary school & 41 & 38.3 & 51 & 48.6 & 35 & 37.6 & 127 & 41.6 & \\
\hline High school & 17 & 15.9 & 9 & 8.6 & 18 & 19.4 & 44 & 14.4 & \\
\hline University & 18 & 16.8 & 11 & 10.5 & 9 & 9.7 & 38 & 12.5 & \\
\hline \multicolumn{10}{|l|}{ Father's education } \\
\hline Primary school & 44 & 41.1 & 40 & 43.0 & 40 & 43.0 & 132 & 43.3 & \multirow{4}{*}{$\begin{array}{c}\chi^{2}=1.52 \\
\mathrm{df}=6 \\
p>0.05\end{array}$} \\
\hline Secondary school & 16 & 15.0 & 16 & 17.2 & 16 & 17.2 & 47 & 15.4 & \\
\hline High school & 32 & 29.9 & 28 & 30.1 & 28 & 30.1 & 91 & 29.8 & \\
\hline University & 15 & 14.0 & 9 & 9.7 & 9 & 9.7 & 35 & 11.5 & \\
\hline \multicolumn{10}{|l|}{ Residence } \\
\hline $\mathrm{W} /$ relatives & 26 & 24.3 & 47 & 44.8 & 33 & 35.5 & 106 & 34.8 & \multirow{4}{*}{$\begin{array}{c}\chi^{2}=11.8 \\
\mathrm{df}=6 \\
p>0.05\end{array}$} \\
\hline Family & 28 & 26.2 & 15 & 14.3 & 23 & 24.7 & 66 & 21.6 & \\
\hline Dormitory & 50 & 46.7 & 41 & 39.0 & 35 & 37.6 & 126 & 41.3 & \\
\hline Home (friend/alone) & 3 & 2.8 & 2 & 1.9 & 2 & 2.2 & 7 & 2.3 & \\
\hline \multicolumn{10}{|l|}{$\begin{array}{l}\text { Statement that she/he thinks } \\
\text { reflects her/him the best }\end{array}$} \\
\hline Being aware of emotions & 32 & 29.9 & 24 & 22.9 & 31 & 33.3 & 87 & 28.5 & \multirow{5}{*}{$\begin{array}{c}\chi^{2}=10.13 \\
\mathrm{df}=8 \\
p>0.05\end{array}$} \\
\hline Being empathic & 20 & 18.7 & 29 & 27.6 & 27 & 29.0 & 76 & 24.9 & \\
\hline Managing the emotions & 22 & 20.6 & 18 & 17.1 & 8 & 8.6 & 48 & 15.7 & \\
\hline Motivating the self & 10 & 9.3 & 8 & 7.6 & 6 & 6.5 & 24 & 7.9 & \\
\hline Social skills & 23 & 21.5 & 26 & 24.8 & 21 & 22.6 & 70 & 23.0 & \\
\hline
\end{tabular}


TABLE 3: Comparison of total scores and subscale mean scores of the emotional intelligence scale according to departments.

\begin{tabular}{lcccc}
\hline Subscales & Natural sciences $(n: 107)$ & Health sciences $(n: 105)$ & Social sciences $(n: 93)$ & Test and $p$ value \\
& $X \pm \mathrm{SD}$ & $X \pm \mathrm{SD}$ & $X \pm \mathrm{SD}$ & $f=26.8, \mathrm{df}=2, p<0.0001$ \\
Awareness of emotions & $21.2 \pm 9.1$ & $27.6 \pm 7.6$ & $28.6 \pm 5.9$ & $f=8.8, \mathrm{df}=2, p<0.0001$ \\
Managing the emotions & $21.5 \pm 8.4$ & $24.9 \pm 6.3$ & $25.2 \pm 5.5$ & $f=21.4, \mathrm{df}=2, p<0.0001$ \\
Motivating the self & $21.5 \pm 8.4$ & $26.5 \pm 6.9$ & $28.1 \pm 6.1$ & $f=17.5, \mathrm{df}=2, p<0.0001$ \\
Empathy & $21.8 \pm 8.5$ & $27.4 \pm 6.8$ & $26.8 \pm 6.5$ & $f=16.2, \mathrm{df}=2, p<0.0001$ \\
Social skills & $21.4 \pm 8.1$ & $26.3 \pm 6.2$ & $26.5 \pm 7.3$ & $f=20.9, \mathrm{df}=2, p<0.0001$ \\
\hline Total & $107.5 \pm 36.1$ & $132.9 \pm 31.4$ & $135.4 \pm 26.3$ & $f$
\end{tabular}

$(28.1 \pm 6.1)$, and "social skills" $(26.5 \pm 7.3)$. However, the subscale of "empathy" $(27.4 \pm 6.8)$ was determined to be higher in health sciences.

\section{Discussion}

In the study, the students were asked about the subscale of emotional intelligence expressing them the best and it was generally determined as subscale of "awareness of emotions" in natural sciences and social sciences and subscale of "empathy" in health sciences. Self-consciousness signifies that the individual knows her/his emotions, as well as strong and weak aspects, is aware of her/his needs and motivations, and understands her/his internal state. Empathy, on the other hand, includes individuals who can comprehend the viewpoints of other people, become good listeners, perceive the unmentioned emotions as well, and understand other people through putting themselves in their shoes. The fact that students consider these subscales expressive might have been caused by both their personal tendencies and their education.

Total scores and subscale mean scores of the emotional intelligence scale were compared according to departments and it was determined that while natural sciences students had a lower level of emotional intelligence, students of health and social sciences had a moderate level of emotional intelligence. Furthermore, the highest mean was determined in students receiving education in the field of social sciences. The fact that students receiving education in the field of social sciences had the highest total score of emotional intelligence might have been caused by the fact that weighted verbal lessons in this field make a contribution to the development of emotional intelligence. In parallel with this study, Çubukcu et al. (2010) also determined in their study that students subjected to the technical program had lower levels of emotional intelligence [18]. In the study of Kuzu and Eker (2010), it was found out that students at the department of nursing had higher mean scores compared to students in the faculty of forestry and technical training faculty, in other words the students subjected to the technical program, and the difference between the groups was statistically significant [19]. There are numerous studies indicating that individuals who completed and continue their education in the field of health have a moderate level of emotional intelligence [16, 20, 21]. A study conducted with preservice teachers determined that the emotional intelligence of preservice teachers was above average [22]. As well as theoretical courses/applications, many factors such as the student-teacher relationships and studentstudent relationships must have also made a contribution to the increase of the level of emotional intelligence in the educational process.

Examining the subscales of emotional intelligence, it was determined that social sciences had the highest score in subscales of "awareness of emotions," "managing the emotions," "motivating the self," and "social skills." However, the subscale of "empathy" was determined to be higher in health sciences. The fact that the department of health sciences had a prominence in the subscale of empathy might be due to the fact that empathy is tried to be planted in students during their vocational training. Empathy required for patient care in nursing, plantation of competences, which are involved in the subscales of emotional intelligence such as therapeutic communication, in the nursing training, and efforts of reflecting them on the field of practice might have contributed to the increase of this subscale. In their study, Kuzu and Eker (2010) determined that students receiving education at the department of nursing had higher mean scores in the subscales of "awareness of emotions" and "motivating the self," which are among the subscales of emotional intelligence, compared to students receiving education in the faculty of forestry and technical training faculty and the difference between the groups was statistically significant [19].

\section{Conclusion}

Consequently, the emotional intelligence level was determined to be lower in natural sciences students and moderate in students of health and social sciences. Among students receiving education in these three different fields, the highest emotional intelligence level was determined in students studying at department of social sciences.

Universities establish an environment where students could develop their emotional intelligence. In order to enable these environments to contribute to development of the emotional intelligence, students should be supported to become skilful at recognizing their own emotions, evaluating their emotional reactions in the face of events, and managing their emotions throughout their education. Besides, this support will make a contribution to students not only during the university period but also after graduation and in their private life to become happy individuals and display a high job performance. Thus, it is required to make regulations in curriculums to develop the emotional intelligence and 
establish social sharing environments to contribute to the emotional intelligence development in students.

\section{Competing Interests}

The authors declare that they have no competing interests.

\section{Authors' Contributions}

Zeynep Karaman Özlü, Gülçin Avşar, Kübra Gökalp, and Serap Ejder Apay contributed to the conception and design of the study. Zeynep Karaman Özlü, Gülçin Avşar, Afife Yurttaş, Özlem Şahın Altun, and Kübra Gökalp contributed to the analysis and interpretation of data. Serap Ejder Apay contributed to statistical analysis and drafted the manuscript. All authors contributed to the critical revision of the manuscript. All authors read and approved the final manuscript.

\section{Acknowledgments}

The authors wish to thank the students of Atatürk University who devoted their time to making this study a success.

\section{References}

[1] P. Salovey and J. D. Mayer, "Emotional intelligence," Imagination, Cognition and Personality, vol. 9, no. 3, pp. 185-211, 1989.

[2] J. D. Mayer, P. Salovey, and D. Caruso, The Mayer-SaloveyCaruso Emotional Intelligence Test (MSCEIT), Multi-Health Systems, Toronto, Canada, 2002.

[3] F. Acar, "Duygusal zeka ve liderlik," in Sosyal Bilimler Enstitüsü Dergisi, vol. 12, pp. 53-68, 2002.

[4] P. Salovey and D. Grewal, "The science of emotional intelligence," APS, vol. 14, no. 6, pp. 281-285, 2005.

[5] J. D. Mayer and P. Salovey, "What is Emotional intelligence?" in Emotional Development and Emotional Intelligence, P. Salovey and D. Sluyter, Eds., pp. 3-31, 1997.

[6] D. Goleman, Why it Can more than IQ? Bantam Books, New York, NY, USA, 1995.

[7] D. Goleman, Working with Emotional Intelligence, Bantam Books, New York, NY, USA, 1998.

[8] C. Cherniss, "Emotional intelligence: what it is and why it matters," in Proceedings of the Annual Meeting of the Society for Industrial and Organizational Pschology, Neworlenas, La, USA, April 2000.

[9] K. Albercht, Sosyal Zeka Başarının Yeni Bilimi. S Göktan (çev.), Timaş Yayınları, Istanbul, Turkey, 2006.

[10] A. N. Dicle, Üniversite Öğrencilerinin Sosyal Beceri Düzeylerinin Duygusal Zeka Düzeyleri ve Bazı Kişisel Özelliklerine Göre Incelenmesi. Yayımlanmamış Yüksek Lisans Tezi, Ondokuz Mayıs Üniversitesi, Sosyal Bilimler Enstitüsü, Samsun, Turkey, 2006.

[11] D. Erginsoy, Duygusal Zeka ve Kişilerarası İlişkiler Tarzları Arasındaki İlişkinin İncelenmesi. Yayımlanmamış Yüksek Lisans Tezi, Atatürk Üniversitesi, Sosyal Bilimler Enstitüsü, Erzurum, Turkey, 2002.

[12] M. Görünmez, Bağlanma Stilleri ve Duygusal Zeka Yetenekleri. Yayımlanmamış Yüksek Lisans Tezi, Bursa, Uludağ Üniversitesi, Sosyal Bilimler Enstitüsü, 2006.
[13] A. Köksal, Ergenlerde Duygusal Zeka İle Karar Verme Stratejileri Arasındaki İlişki. Yayımlanmamış Yüksek Lisans Tezi, İstanbul Üniversitesi, Sosyal Bilimler Enstitüsü, İstanbul, Turkey, 2003.

[14] J. Fuimano, "Raise your emotional intelligence," Nursing Management, vol. 35, no. 7, pp. 10-13, 2004.

[15] D. Goleman, İşbaşında Duygusal Zeka, Varlık Yayınları, Istanbul, Turkey, 2000.

[16] G. Avsar and M. Kasikci, "Hemşirelik Yüksekokulu Öğrencilerinde Duygusal Zeka Düzeyi," Anadolu. Hemşirelik ve Sağlık Bilimleri Dergisi, vol. 13, no. 1, pp. 1-6, 2010.

[17] E. F. Ergin, Üniversite Öğrencilerinin Sahip Oldukları Duygusal Zeka Düzeyi İle 16 Kişilik Özelliği Arasındaki İlişki Üzerine Bir Araştırma. Yayınlanmamış Yüksek Lisans Tezi, Selçuk Üniversitesi, Sosyal Bilimler Enstitüsü, Konya, Turkey, 2000.

[18] M. İ. Çubukcu, Ç. Özkan, S. Birgül, M. Alaslan, and H. Özbayrak, Düzce MYO ögrencilerinde duygusal zekâ(EQ) derecelerinden okudukları bölümlere ve başarı durumlarına göre değerlendirilmesi, Ulusal Meslek Yüksekokulları Öğrenci Sempozyumu, 2010.

[19] A. Kuzu and F. Eker, "Hemşirelik öğrencilerinin duygusal zeka ve iletişim becerilerinin diğer üniversite öğrencileri ile karşılaştırmalı olarak değerlendirilmesi," Hemşirelikte Araştırma Geliştirme Derneği Anasayfa, vol. 3, pp. 14-29, 2010.

[20] A. M. Beauvais, N. Brady, E. R. O'Shea, and M. T. Quinn Griffin, "Emotional intelligence and nursing performance among nursing students," Nurse Education Today, vol. 31, no. 4, pp. 396-401, 2011.

[21] E. Codier, B. M. Kooker, and J. Shoultz, "Measuring emotional intelligence of clinical staff nurses," Nursing Administration Quarterly, vol. 32, no. 1, pp. 8-14, 2008.

[22] I. Gürşimşek, D. E. Vural, and E. S. Demirsöz, "Öğretmen adaylarının duygusal zekâları ile iletişim becerileri arasındaki ilişki," Mehmet Akif Ersoy Üniversitesi Eğitim Fakültesi Derg, vol. 8, no. 16, pp. 1-11, 2008. 


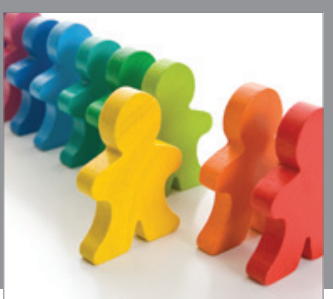

Autism

Research and Treatment
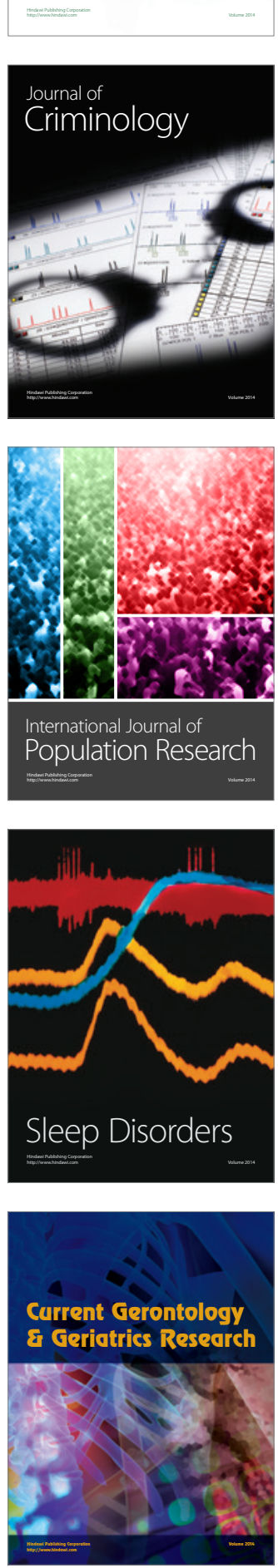

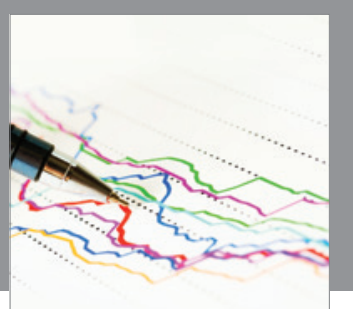

Economics

Research International
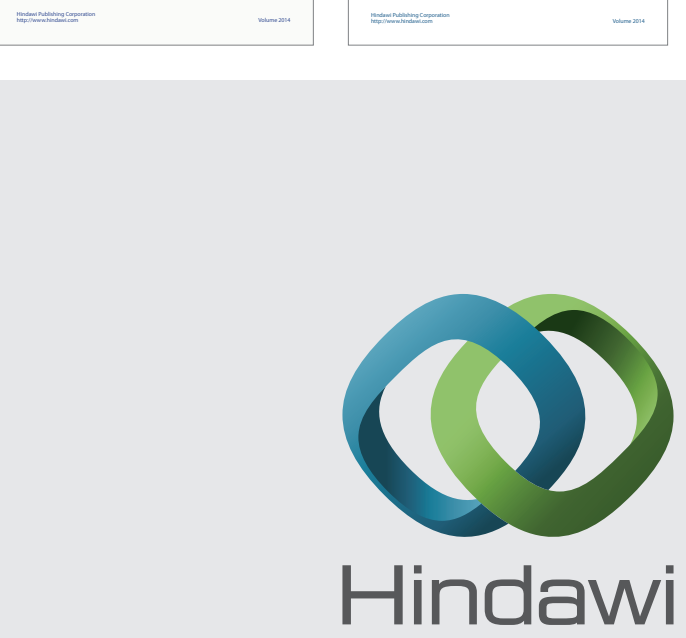

Submit your manuscripts at

http://www.hindawi.com

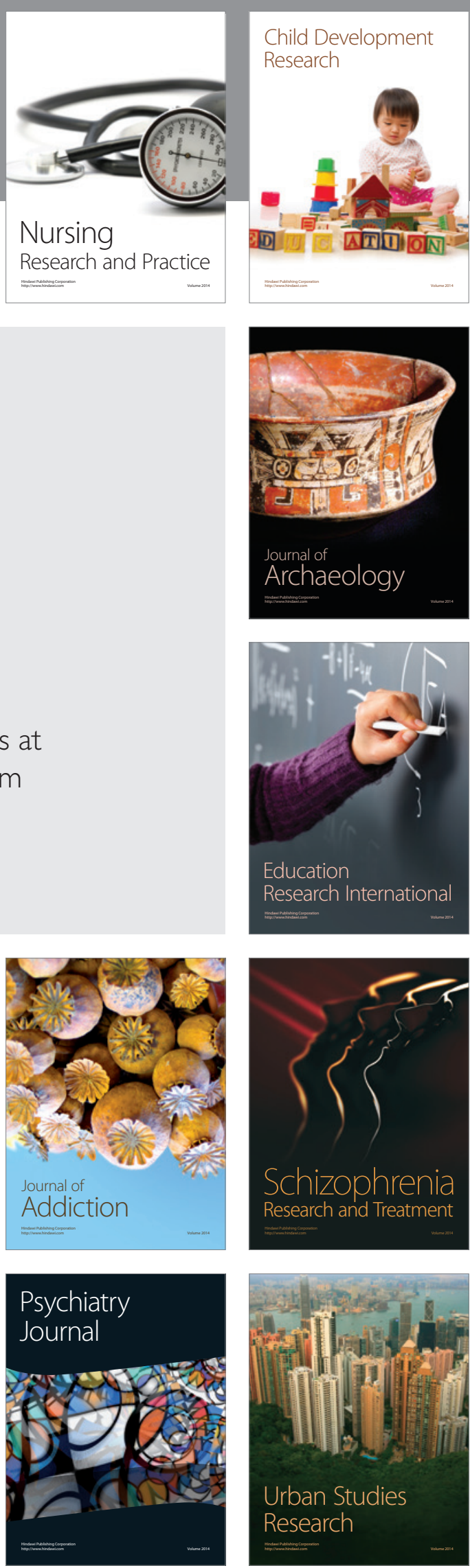